\title{
PROBLEMS WITH THE 2013 CURRICULUM CHANGE ON THE QUALITY OF TEACHER TEACHING
}

\author{
Wahyu Pramesti, Mauliddhina Imas Permatasari, Muhamad Chamdani \\ Universitas Sebelas Maret \\ wahyualdiyan@gmail.com
}

\section{Article History}

accepted 30/09/2018

approved $12 / 10 / 2018$

published 30/10/2018

\section{Keywords}

curriculum 2013, problems, teaching

\begin{abstract}
Curriculum always develops following the current times. the change of curriculum implementation encountered many obstacles both from schools, teachers and students. . This research is a qualitative descriptive study. Data collection techniques used are questionnaires. this research aims to identify the problems of teachers in implementing the 2013 curricullum learning in elementary schools. this research is expected can give useful information about the 2013 curriculum problem on how the way the teacher teaches to improve the teaching learning qualityThe results of the study show that the problems of teachers come from the government, teachers, and students. The problems of the teacher include learning media, learning materials, learning methods, and the integration of the lessons learned in thematic learning. Students' problems are adaptation to thematic learning in the 2013 curriculum. The conclusion is that the implementation of the 2013 curriculum with good teacher quality can improve learning in school.
\end{abstract}

Social, Humanities, and Education Studies (SHEs): Conference Series https://jurnal.uns.ac.id/shes
p-ISSN 2620-9284 e-ISSN 2620-9292 


\section{PENDAHULUAN}

Kurikulum senantiasa berkembang mengikuti perkembangan zaman. Sejak merdeka, Indonesia telah mengalami beberapa pergantian kurikulum. Pergantian kurikulum yang terbaru adalah kurikulum 2013 yang dilaksanakan sejak tahun 2013. Kurikulum mengandung pengertian suatu perangkat yang dijadikan acuan dalam mengembangkan suatu proses pembelajaran yang berisi kegiatan-kegiatan siswa. Dengan adanya pergantian kurikulum, diharapkan akan memberi arah untuk menempatkan peserta didik sebagai subjek yang peduli pada lingkungan sosial, alam, dan lingkungan budaya (Kurniasih, I., \& Sani, B. Sani, 2014:3). Implementasi kurikulum 2013 pada kenyataanya masih banyak menemui kendala, baik kendala dari pihak sekolah, siswa maupun guru.

Salah satu aspek yang dapat menunjang berhasilnya kurikulum merupakan kualitas guru dalam pembelajaran. Sani, R. A. (2013:2) Kualitas guru dilihat dari keberhasilan peserta didiknya sehingga dikatakan bahwa guru yang hebat (great teacher) itu adalah guru yang dapat memberikan inspirasi bagi peserta didiknya. Kompetensi profesional guru Sekolah Dasar/Madrasah Ibtidaiyah yaitu kompetensi yang harus dimiliki oleh guru pada tingkat SD/MI terhadap kemampuannya dalam melaksanakan tugas-tugasnya di sekolah yang mengacu pada Permendiknas Nomor 16 Tahun 2007 tentang Standar Kualifikasi Akademik dan Kompetensi Guru yang menjelaskan bahwa kompetensi profesional yaitu: 1) Menguasai materi, struktur, konsep, dan pola pikir keilmuan yang mendukung mata pelajaran yang diampu,2) menguasai standar kompetensi dan kompetensi dasar mata pelajaran/bidang pengembangan yang diampu, 3) mengembangkan materi membelajaran yang diampu secara kreatif, 4) mengembangkan keprofesionalan secara berkelanjutan dengan melakukan tindakan reflektif, 5) memanfaatkan teknologi informasi dan komunikasi untuk berkomunikasi dan mengembangkan diri. (Nursalim, N., 2017:252).

Guru berperan penting dalam menentukan mutu pendidikan di sekolah, mengingat guru pada kenyataannya mampu memberi motivasi kepada masyarakat akan pentingnya pendidikan anak-anaknya. Status yang tinggi menurut penilaian masyarakat menuntut tampilnya perilaku guru yang terhormat sebagai penyandang profrsi. Adapun profil guru yang diharapkan di era globalisasi yaitu memiliki kepribadian yang matang dan berkembang, menguasai IPTEK, memiliki ketrampilan yang membangkitkan minat peserta didik dan pengembangan profesi yang berkesinambunga. Secara administratif, pemerintah pusat telah menyiapkan perangkat pelaksanaan pembelajaran yang tidak perlu lagi disiapkan oleh guru. Namun, guru dituntut berperan secara aktif sebagai motivator dan fasilitator dalam pembelajaran sehingga siswa akan menjadi pusat belajar (student center). Hal ini menjadi kendala tersendiri bagi para guru karena tidak semua guru memiliki kompetensi tersebut. Selain itu, guru dituntut kesiapannya untuk melaksanakan dalam waktu yang relative singkat, sementara perangkat pembelajarannya belum disiapkan secara matang. (Widagdorini, Niken $\mathrm{H}, 2017: 1$ ).

Guru yang berkompeten adalah menguasai secara cermat dan jelas apa-apa yang hendak diajarkan. Seorang guru yang tidak menguasai bahan ajar, tidak mungkin dapat mengajar dengan baik kepada para siswanya. Oleh karena itu, penguasaan bahan ajar merupakan syarat bagi guru. Hal penting dalam pembelajaran setelah guru menguasai bahan ajar adalah peran guru dalam mengelola pembelajaran. Pengelolaan pembelajaran menjadi hal penting karena berkaitan langsung dengan aktivitas belajar siswa. Dengan demikian, untuk mendapatkan proses dan hasil belajar siswa yang baik tentu memerlukan kinerja guru yang berkualitas seperti membuat RPP, media pembelajaran, metode, model pembelajaran (Widagdorini, Niken $\mathrm{H}, 2017: 4$ ).

Dalam mengimplementasikan kurikulum, yang jauh lebih penting adalah guru sebagai ujung tombak dalam pelaksanakan kurikulum. Oleh karena itu sangat penting kesiapan guru dalam mengimplementasikan kurikulum itu selain kompetensi, komitmen 
dan tanggung jawabnya. Kompetensi guru bukan saja menguasai apa yang harus diajarkan tapi bagaimana membelajarkan siswa yang menantang, menyenangkan, memotivasi, menginspirasi dan memberi ruang kepada siswa untuk melakukan keterampilan proses yaitu mengobservasi, bertanya, mencari tahu, merefleksi. Implementasi kurikulum 2013 merupakan aktualisasi kurikulum dalam pembelajaran dan pembentukan kompetensi serta karakter perserta didik. Hal tersebut menuntut keaktifan guru dalam mennciptakan dan menumbuhkan berbagai kegiatan sesuai dengan rencana yang telah diprogramkan.

Krissandi, Sagita D.A dan Rusmawan (2015:458) Kurikulum 2013 pada awal diimplementasikannya telah menuai banyak kontroversi. Penyiapan kurikulum 2013 dinilai terlalu terburu-buru dan tidak mengacu pada hasil kajian yang sudah matang berdasarkan hasil KTSP dan kurang memperhatikan kesiapan satuan pendidikan dan guru. Meskipun demikian, kurikulum 2013 tetap dilaksanakan secara bertahap mulai tahun pelajaran 2013/2014. Kementrian Pendidikan dan Kebudayaan (Kemendikbud) menjelaskan bahwa tahun 2010-2035 adalah bonus demografi bagi Indonesia dalam mempersiapkan generasi emas karena jumlah penduduk dnegan usia sekolah sangat tinggi.

Purwandari, Ganis M. (2015:3) Problematika penerapan kurikulum 2013 bagi guru yaitu guru yang kurang siap dalam menggunakan kurikulum baru ini, media yang harus selalu disertakan dalam setiap proses pembelajaran yang belum tentu semua guru mempersiapkannya, metode dan strategi yang harus disusun agar sesuai dengan acuan kurikulum 2013, sampai penilaian proses dan hasil yang dirasa rumit oleh guru dan kesiapan siswa atau sekolah itu sendiri.

Pada kenyataannya kegiatan pembelajaran SD Negeri di Kecamatan Kebumen sudah melaksanakan kurikulum 2013. Berdasarkan hasil observasi dan wawancara dengan seorang guru SD Negeri di Kecamatan Kebumen memberikan keterangan bahwa dalam pelaksanaan kurikulum 2013 masih menemukan banyak kendala. Dari mulai kebingungan dalam merancang proses pembelajaran. Guru lebih banyak menggunakan metode ceramah di dalam mereka mengajar dibandingkan dengan memenuhi karakteristik pembelajaran tematik yang seharusnya mereka jalankan. Pendekatan saintifik yang merupakan dasar dari kurikulum 2013 terkadang tidak dilaksanakan oleh guru karena selain memakan waktu yang banyak, juga diperlukan metode dan media pendukung untuk melaksanakannya. Berdasarkan fakta tersebut, maka diperlukan adanya pengkajian mengenai hambatan dalam pelaksanaan kurikulum 2013 di Sekolah Dasar. Oleh karena itu, peneliti memilih sekolah yang telah melaksanakan kurikulum 2013 yaitu SD Negeri di Kecamatan Kebumen tempat penelitian.

Berdasarkan uraian di atas, maka peneliti tertarik melakukan penelitian tentang Problematika Penerapan Kurikulum 2013 Terhadap Kualitas Mengajar Guru. Penelitian ini digunakan untuk mengetahui bagaimana bentuk kinerja atau kualitas mengajar guru dalam menerapkan kurikulum 2013, kendala yang dihadapi guru dalam menerapkan kurikulum 2013, serta upaya yang perlu dilakukan guru untuk mengatasi problematika dalam menerapkan kurikulum 2013. Dengan demikian dalam penelitian ini peneliti mengambil judul "Problematika Penerapan Kurikulum 2013 Terhadap Kualitas Mengajar Guru”.

\section{METODE}

Teknik pengumpulan data merupakan cara yang digunakan peneliti untuk mendapatkan data dalam suatu penelitian. Pada penelitian ini mengguanakan pendekatan deskripsi kualitatif. Subjek dalam penelitian ini adalah guru di Kecamatan Kebumen yang berjumlah 12 guru. Penelitian ini menggunakan teknik pengumpulan data berupa angket dengan instrument lembar angket. Teknik analisis data dengan menggunakan reduksi data, display data dan penarikan kesimpulan. 
HASIL DAN PEMBAHASAN

Menurut Mulyasa (2014:66), kurikulum 2013 merupakan tindakan lanjut dari kurikulum berbasis kompetensi (Competency Based Curriculum) dijadikan acuan dan pedoman bagi pelaksanaan pendidikan untuk mengembangkan berbagai ranah pendidikan (pengetahuan, keterampilan, dan sikap) dalam seluruh jenjang dan jalur pendidikan, khususnya pada jalur pendidikan sekolah. Budi (2014:4) mengatakan bahwa kurikulum 2013 adalah suatu proses pendidikan yang mmeberikan kesempatan bagi siswa agar dapat mengembangkan segala potensi yang mereka miliki menjadi kemampuan yang semakin lama semakin meningkat dilihat dari aspek sikap (afektif), pengetahuan (kognitif), dan keterampilan (psikomotor). Berdasarkan beberapa pengertian di atas, dapat disimpulkan bawa kurikulum 2013 merupakan tindak lanjut dari kurikulum berbasis kompetensi yang bertujuan untuk meningkatkan aspek sikap, pengetahuan, dan keterampilan.

Implementasi dalam kamus besar bahasa Indonesia diartikan sebagai pelaksanaan atau penerapan, sehingga implementasi kurikulum dapat diartikan sebagai pelaksanaan dari kurikulum yang telah dirancang/didesain ke lapangan atau ke setiap satuan pendidikan. Kurikulum 2013 telah diimplementasikan sejak tahun ajaran baru 2013/2014. Pada tahun 2013 kurikulum 2013 mulai diimplementasikan dengan sasaran uji coba pada satuan pendidikan tingkat Sekolah Dasar (SD) kelas I dan IV, tahun 2014 pengimplementasian kurikulum 2013 menjadi kelas I, II, IV, dan V, dan pada tahun 2015 ini menjadi seluruh kelas yaitu kelas I, II, III, IV, V, dan VI. Namun tidak semua sekolah menerapkan kurikulum 2013, sekolah-sekolah yang menjadi sasaran uji coba memiliki kriteria ditentukan oleh pemerintah.

Menurut Kamus Besar Bahasa Indonesia Edisi Keempat (2008), problematika merupakan sesuatu yang menimbulkan masalah atau permasalahan. Sehingga permasalahan merupakan segala sesuatu yang menghalangi tercapainya suatu tujuan. Menurut Undang-Undang nomor 14 tahun 2005, "guru adalah pendidik profesional dengan tugas utama mendidik, mengajar, membimbing, mengarahkan, melatih, menilai, dan mengevaluasi peserta didik pada pendidikan anak usia dini jalur pendidikan formal, pendidikan dasar, dan pendidikan menengah". Guru adalah komponen yang mempunyai peran besar dalam keberhasilan suatu pembelajaran. Hal ini dikarenakan guru selalu terlibat langsung dengan siswa. Terkait dengan pembelajaran, guru berperan mulai dari perencanaan, pelaksanaan hingga penilaian pembelajaran. Peranan tersebut berhubungan dengan kemampuan yang dimiliki guru.

Adapun yang mempengaruhi guru dalam mempersiapkan, melaksanakan dan mengevaluasi pembelajaran dapat berasal dari internal guru maupun eksternal. Faktor internal yaitu kondisi yang berasal dari diri guru sendiri, sedangkan faktor eksternal berasal dari luar yang mempengaruhi kinerja guru. Hal yang mempengaruhi itu dapat mendukung pembelajaran ataupun sebaliknya, yaitu menghambat pembelajaran. Penelitian ini dilakukan untuk mencari hambatan pembelajaran terutama dalam pembelajaran kurikulum 2013. Hambatan yang akan dicari dalam penelitian ini adalah yang bersumber dari guru. Dari sumber ini dapat diketahui hambatan apa saja yang mempengaruhi kualitas pembelajaran kurikulum 2013 termasuk faktor-faktor penghambat yang berasal di luar sumber tetapi berdampak pada sumber (guru).

Untuk memperoleh data tentang problematika penerapan kurikulum 2013 terhadap kualitas mengajar guru, maka peneliti menyebarkan angket sebanyak 10 item pernyataan. Masing-masing pernyataan memiliki 3 alternatif jawaban selalu, jarang, tidak pernah. Sehingga dapat diketahui problematika penerapan kurikulum 2013 di Kecamatan Kebumen yaitu (1) Materi dalam buku siswa terlalu dangkal, sehingga perlu adanya buku pendamping lain atau sumber belajar lain untuk menunjang pembelajaran, (2) Pembelajaran menggunakan kurikulum 2013 tetapi saat ujian akhir menggunakan kurikulum atau disamakan dengan KTSP menjadi masalah yang dihadapi guru kelas $\mathrm{VI}$ untuk mempersiapkan peserta didiknya dalam menghadapi 
ujian akhir, (3) Guru sudah mendapatkan pelatihan, namun saat pelatihan guru lebih banyak terbebani dengan masalah penilaian yang menuntut guru lebih banyak administrasi, (4) Guru merasa terbebani dengan penilaian autentik karena memiliki 3 aspek yaitu pengetahuan, sikap dan keterampilan yang masing-masing di dapat dari nilai yang berbeda-beda, (5) Guru jarang membuat atau memakai media pembelajaran, (6) Guru masih dominan menggunakan metode ceramah. Dapat simpulkan bahwa implementasi kurikulum 2013 masih banyak menemui kendala. Banyaknya masalah yang timbul dalam implementasi Kurikulum 2013 ini menimbulkan berbagai masalah khususnya pada guru.

Untuk mengatasi problematika kurikulum 2013 yaitu melakukan persiapan sebelum melakukan pembelajaran, karena itu adalah hal yang wajib dilaksanakan guru. Secara umum persiapan implementasi pembelajaran tematik integratif yang dilakukan oleh guru dengan mempersiapkan buku siswa dan buku guru yang akan digunakan, menganalisi KD yang ada dalam buku guru, menganalisi buku siswa, menyusun RPP dengan beberapa penyesuaian yang dibutuhkan oleh peserta didik, menyiapkan media dan alat pembelajaran. Media yang dipersiapkan disesuaikan dengan tema atau materi yang akan diajarkan tidak semua materi guru selalu membuat media, hanya materi yang dirasa sulit guru membuat media agar siswa lebih paham dalam mendalami materi, namun jika materi dirasa mudah guru tidak membuat media pembelajaran. Media pembelajran dapat berupa powerpoint yang ditampilkan lewat LCD. Persiapan yang terakhir yaitu instrument penilaian.

Berdasarkan hasil penelitian, guru SD di Kecamatan Kebumen sudah melaksanakan pembelajaran sesuai dengan pembelajaran kurikulum 2013, yaitu tidak terlihat pemisahan antar beberapa mata pelajaran yang dipadukan, dan sudah menggunakan tema dalam setiap pembelajaran yang dilakukan. Hal ini sesuai dengan pengertian pembelajaran tematik integratif dalam Permendikbud Nomor 57 Tahun 2014 tentang Kurikulum 2013 Sekolah Dasar/Madrasah Ibtidaiyah, yaitu pembelajaran yang mengintegrasikan berbagai kompetensi dari berbagai mata pelajaran ke dalam berbagai tema.

Pelaksanaan pembelajaran tematik integratif yang dilakukan guru SD di Kecamatan Kebumen terdiri dari kegiatan pendahuluan, kegiatan inti, dan kegiatan penutup. Hal ini juga sudah sesuai dengan Permendikbud Nomor 103 Tahun 2014 tentang Pembelajaran pada Pendidikan Dasar dan Pendidikan Menengah yang menjelaskan bahwa tahapan dalam pembelajaran terdiri dari kegiatan pendahuluan/awal, kegiatan inti, dan kegiatan penutup.

Guru-guru sudah melaksankan penilaian autentik yang menilai tiga aspek yaitu aspek sikap, aspek pengetahuan dan aspek keterampilan. Aspek sikap dinilai melalui kebiasaan peserta didik sehari-hari saat pembelajaran berlangsung dilihat peserta didik yang menonjol, aspek pengetahuan di nilai dengan pemberian ulangan harian dan tugas-tugas, dan aspek keterampilan dinilai setiap hari saat pembelajaran berlangsung.

\section{SIMPULAN}

Problematika penerapan kurikulum 2013 di Kecamatan Kebumen adalah materi dalam buku siswa terlalu dangkal, sehingga perlu adanya buku pendamping lain atau sumber belajar lain untuk menunjang pembelajaran, pembelajaran menggunakan kurikulum 2013 tetapi saat ujian akhir menggunakan kurikulum atau disamakan dengan KTSP menjadi masalah yang dihadapi guru kelas VI untuk mempersiapkan peserta didiknya dalam menghadapi ujian akhir, guru sudah mendapatkan pelatihan, namun saat pelatihan guru lebih banyak terbebani dengan masalah penilaian yang menuntut guru lebih banyak administrasi, guru merasa terbebani dengan penilaian autentik karena memiliki 3 aspek yaitu pengetahuan, sikap dan keterampilan yang masing- 
masing di dapat dari nilai yang berbeda-beda, guru jarang membuat atau memakai media pembelajaran, guru masih dominan menggunakan metode ceramah. Untuk mengatasi problematika kurikulum 2013 sehingga kualias mengajar guru lebih baik maka perlu menyiapkan dan memahami buku siswa dan buku guru, membuat RPP dengan beberapa penyesuaian yang disesuaikan untuk kebutuhan peserta didik, menyediakan alat dan media pembelajaran yang akan digunakan. Media yang digunakan tidak harus setiap pembelajaran guru membuat media, guru memilah-milah mana materi yang dirasa sulit yang membutuhkan penggunaan media pembelajaran, dan yang dirasa mudah tidak menggunakan media pembelajaran, menyiapkan instrumen penilaian.

\section{DAFTAR PUSTAKA}

Budi, B. S. (2014). Strategi Guru dalam Menghadapi Kurikulum 2013 di SMA Negeri 2 Surakarta. Skripsi Tidak Dipublikasikan. Universitas Sebelas Maret, Surakarta.

Hartono, R. (2017). GURU PROFESIONAL. Jurnal Dosen Universitas PGRI Palembang.Krissandi, A. D. S., \& Rusmawan, R. (2015). Kendala guru sekolah dasar dalam implementasi Kurikulum 2013. Cakrawala pendidikan, (3).

Kurniasih, I., \& Sani, B. (2014). Implementasi Kurikulum 2013 Konsep \& Penerapan. Surabaya: Kata Pena.

Mulyasa, H. E. (2014). Pengembangan dan Implementasi Kurikulum 2013. Bandung: Remaja Rosdakarya.

Nursalim, N. (2017). PROFESIONALISME GURU SD/MI. Lentera Pendidikan: Jurnal IImu Tarbiyah dan Keguruan, 20(2), 250-25

Peraturan Pemerintah Republik Indonesia Nomor 19 Tahun 2005 tentang Standar Nasional

Purwandari, Ganis M. (2015). IDENTIFIKASI FAKTOR PENGHAMBAT PELAKSANAAN KURIKULUM 2013 DI SD NEGERI JLABAN SENTOLO KULON PROGO. Universitas Negeri Yogyakarta.

Sani, R. A. (2013). Inovasi pembelajaran. Jakarta: Bumi Aksara.

Widagdorini, Niken H. (2017). Kinerja Guru dalam Meningkatkan Mutu Pendidikan Melalui Kurikulum 2013 di SD Negri Timpik 1 Tahun 2017 (Doctoral dissertation, Universitas Muhammadiyah Surakarta). 